\title{
Schinus Terebinthifolia Raddi: A Comparative Framework On Population Genetic Structure In A Restored Area After 12 Years*
}

Erica Moraes Santos de Souza

Instituto Federal de Sergipe

Sheila Valéria Álvares-Carvalho

Universidade Federal de Sergipe

Robério Anastácio Ferreira

Universidade Federal de Sergipe

Renata Silva Mann ( $\nabla$ renatamann@gmail.com )

Universidade Federal de Sergipe https://orcid.org/0000-0001-5993-3161

\section{Research Article}

Keywords: inbreeding, restoration monitoring, pink pepper, effective size.

Posted Date: December 16th, 2021

DOI: https://doi.org/10.21203/rs.3.rs-1171854/v1

License: (c) (i) This work is licensed under a Creative Commons Attribution 4.0 International License.

Read Full License

Version of Record: A version of this preprint was published at Genetic Resources and Crop Evolution on April 18th, 2022. See the published version at https://doi.org/10.1007/s10722-022-01384-9. 


\section{Abstract}

The success of restoration projects depends upon the genetic diversity of the implanted species. It is a limiting factor, often because the seed sources are immersed in highly fragmented landscapes. This work was carried out to compare the genetic diversities of the juveniles and the adult trees of Schinus terebinthifolia Raddi in a mixed reforestation area, both in the restoration process and in the remaining natural area in the Atlantic Forest. Through five SSR primers, it was observed that the implanted population showed a greater genetic diversity index $(\mathrm{He})(0.553$ adults and 0.505 juveniles) when compared to the wild population ( 0.487 adults and 0.483 juveniles). It indicated that the forested area was established with individuals of high genetic diversity. There was a reduction of genetic diversity, with the loss of exclusive alleles and maintenance of inbreeding and coancestry in the juveniles of the reforested population. It can be inferred that there was a low gene flow among the fragments. The effective population size in both populations (adults and juveniles) was lower than that recommended for conserving populations in the short and long terms. These results have shown that continuous monitoring of this particular area is of absolute necessity and for applying techniques that can promote the connectivity of the fragments. It would allow for a more significant reduction of genetic drift and the persistence of the planted populations.

\section{Introduction}

The exploitation of natural resources in an unsustainable way has resulted in a reduction in the number of forested areas in the different biomes of Brazil. According to the latest SOS Mata Atlântica Report (2016), when summing up all of the fragments of the native forest above 100 ha, there were $8.5 \%$ Atlantic Forest remnants (biodiversity hotspot) about the original cover. This scenario can be further aggravated since $72 \%$ of the Brazilian population lives within this domain. However, actions are being developed to compensate for the damages caused by anthropic activities on the forest's composition, such as increasing the forested areas through forest restoration projects. It can be cited, as an example, that the Pact for the Restoration of the Atlantic Forest aims to recover 15 million hectares of forest by the year 2050 (Rodrigues et al., 2011). However, for these projects to be successfully developed, many seeds and seedlings are necessary.

The seeds collected for seedlings aiming for restoration projects must originate from these kinds of populations, along with reasonable levels of genetic variability and a minimal amount of inbreeding (Sebbenn et al., 2003). Genetic variability can play a decisive role in the survival of a species, especially when there is an unexpected alteration of the environment, for it will then become increasingly important, as this will be a determinant of the success of the ecological restorationist actions (Sebbenn, 2002; Vencovski and Crossa, 2003; Rodrigues et al., 2009; Mijangos et al., 2015). Thus, new restoration projects may also need to consider the recovery of genetic diversity and the revival of floristic diversity. The objective is to achieve the new population's establishment (Kageyama and Gandara, 2004; Rodrigues et al., 2009). 
Among the 17 States of Brazil that are within the territorial limits of the Atlantic Forest, the State of Sergipe has the most fragments that are less than 50 ha (Sergipe, 2014). The collection of native species seeds, as part of the restoration projects in the State of Sergipe, is often complex due to the small number of individuals with seeds that are present in any fragment, which is also deemed to be within the necessary reliable distances for sampling. As a result, the few genotypes represented in the lots of forest seeds collected may lead to the production of seedlings of related individuals, thus resulting in endogamy (Álvares-Carvalho et al., 2017).

Although some natural populations of S. terebinthifolia in the State of Sergipe present high levels of genetic diversity, these are in decline because they present a recent genetic bottleneck. It contributes to reducing genetic diversity in the future through the amount of increased inbreeding (Álvares-Carvalho et al., 2015). This scenario, an alternative to maintaining the species' genetic heritage, is in reforestation projects, which are then associated with a potential to recover the degraded areas. The Schinus terebinthifolia Raddi (pink pepper - Anacardiaceae) species has environmental and socio-economic importance for its regions of natural occurrence in Brazil. It is a pioneer species, being dioecious, with a cross-pollinating strategy (allogamy) that depends upon biotic agents, such as bees, flies, and wasps (Lenzi and Orth, 2004).

The poivre rose, also called aroeira, is commonly used in restoration projects due to its plasticity and rusticity. Its fruits are appreciated as a condiment in the national and international marketplace. They contribute to $20 \%$ of the income of the communities of fishermen who gather them (Jesus and Gomes, 2013). However, fruits collection in a non-sustainable way may imply, over the years, a reduction in the number of individuals. Thus, compromising the genetic structure and the self-sustainability of the natural populations. The fruits used mainly by the local extractivist for collection and sale are widely used to recover degraded areas and ecological restorations. Being a pioneering species of fast growth, which produces flowers and fruits early, accelerates natural regeneration processes in its implanted areas. In addition, the species has also become necessary because of its economic importance since the communities nearby the low course of São Francisco River harvest its fruits and seeds for commercialization. Therefore, this current work was carried out to evaluate the adult and juvenile $S$. terebinthifolia individuals' current diversity scenarios in a mixed reforestation area in the Atlantic Forest after 12 years of implantation.

\section{Methods}

\subsection{Collection of the Plant Materials}

The young leaves were collected from 309 individuals of $S$. terebinthifolia that were distributed in two populations: one, in mixed reforestation (Reflo) area and another one, in a natural fragment (Nat), both located in an area of the Atlantic Forest, in the State of Sergipe, Northeastern Brazil. The reforested area (Reflo) is a private property belonging to the Votorantim Cimentos S.A. (Cimentos Sergipe S.A. - CIMESA) Company, which is located in the municipality of Laranjeiras (10S 48' 22" and 37W 10'18"). The North 
and East area are fragments of native vegetation (Semidecidual and Mangrove Seasonal Forest). At the same time, to the South and West, it is an anthropized area (roads and companies). In 2005, this reforestation was carried out in an area previously cultivated by a conventional agriculture system with sugar cane crops. The implantation of the native species reforestation was carried out using a model quincunx system (four pioneer species and one central climax species), where 34 native Atlantic Forest tree species of different ecological groups were planted. In the Reflo population, a census was carried out in eight plots (30 m x $20 \mathrm{~m}$, each), where a total of 82 adults (implanted individuals) and 121 juveniles (regenerants) were identified and had their biological material collected for this study.

The second area (Nat) is a natural fragment that is located in the Northern region of the State of Sergipe, in the municipality of Neopolis (10S 16' 37.80" and 36W 42' 28.79"). This fragment belongs to the Permanent Preservation Area (PPA), on the banks of the main river of the Brazilian Northeast, the São Francisco River. In the Nat population, the collection was in a plot with $50 \mathrm{~m} \times 50 \mathrm{~m}$, with 74 adults and 32 juveniles. For the juvenile stage of this population, a height of up to $2 \mathrm{~m}$ was adopted. Geographical coordinates of all of the individuals were addressed through the Global Positioning System (GPS). The individuals were evaluated for their diversity through the use of SSR markers. DNA of the leaves was obtained by the optimized CTAB method, with $0.2 \%$ of 2-mercaptoethanol (v/v) (Nienhuis et al., 1995).

\subsection{Genotyping}

The DNA fragments of all of the individuals were amplified in a Thermocycler by using five nuclear microsatellite sequences (Saat 09, Saat 17, Saat 25, Saat 47, and Saat 55) (Williams et al., 2002). The total volume of each amplified sample corresponded to $12.0 \mu \mathrm{L}: 2.0 \mu \mathrm{L}$ of DNA ( $5 \mathrm{ng} / \mu \mathrm{L}$ ) was added to $10.0 \mu \mathrm{L}$ of the reaction mix [1.3 $\mu \mathrm{L}$ of $10 X$ PCR buffer ( $10 \mathrm{mM}$ Tris- $\mathrm{HCl} \mathrm{pH} \mathrm{8.3,50} \mathrm{mM} \mathrm{KCl),} 1.0 \mu \mathrm{dNTP}$ $(2.5 \mathrm{mM}), 0.2 \mu \mathrm{l}$ Taq polymerase (Ludowig) $(1 \mathrm{U})$ and $1.0 \mu$ leach primer $(2 \mu \mathrm{M})$. The final volume was completed with ultrapure water].

Reactions for the DNA amplification were performed on a GenePro Bioer Technology Thermocycler. Thirty-five cycles of amplification, consisting of a 5 min initiation step at $94^{\circ} \mathrm{C}$, with denaturation at $94^{\circ} \mathrm{C}$ for $1 \mathrm{~min}$, then annealing the SSR primers at a consistent temperature for each of the five primers for 40 sec, together with an extension at $72^{\circ} \mathrm{C}$ for $1 \mathrm{~min}$. At the end of this stage, an extension step occurred at $72^{\circ} \mathrm{C}$ for $10 \mathrm{~min}$.

After the reactions, the amplification products were separated by electrophoresis in an $8 \%$ polyacrylamide gel at $130 \mathrm{~V}, 20 \mathrm{~mA}$, and $2 \mathrm{~W}$ for $3 \frac{1}{2}$ hours. After the electrophoresis, the gel was stained with silver nitrate solution ( $0.2 \% \mathrm{AgNO})$ ) and then developed with a $3 \% \mathrm{HNO} 3$ solution and formaldehyde (60 $\mu \mathrm{L} / 100 \mathrm{~mL}$ of $3 \% \mathrm{HNO}$ solution). $20 \mathrm{bp}$ and $100 \mathrm{bp}$ ladders were used.

\subsection{Genetic Analyzes}

The observed heterozygosity (Ho) and the expected heterozygosity (He) (genetic diversity of Nei, 1978) were calculated by using GenAlEx Software Version 6.2 (Peakall and Smouse, 2012). The inbreeding 
coefficient, inferred from the estimation of the fixation index (F), as well as the allelic richness (AR), were both obtained with FSTAT Software Version 2.9.3.2 (Goudet, 1995). The genetic data were obtained for both the adult and the juvenile areas.

Based upon the number of individual's sampled (n), the coancestry coefficient (Fij) and the fixation index of each population $(F)$, together with the adequate size of the inbreeding for the adults and the juveniles, were based on Sebbenn and Seoane (2005):

$\mathrm{Ne}=0.5 \mathrm{n} 2 /\left[(1+F)^{\star}(0.5 \mathrm{n}+\llbracket n x=1 \rrbracket n y \neq 1 \rrbracket x y)\right]$

$\mathrm{Ne}=$ the effective size of the inbreeding;

$\mathrm{n}=$ the number of individuals from each population;

$F=$ the coefficient of inbreeding, inferred from the estimation of the index of fixation;

and $\llbracket n x=1 \llbracket n y \neq 1 \llbracket x y=$ the sum of all of the coancestry among the pairs of individuals of each population.

The coancestries were inferred from the kinship coefficients (Loiselle et al., 1995) with SPAGeDi 1.2 (Hardy and Vekemans, 2002). The genetic representativity ( $\mathrm{Ne} / \mathrm{n}$ ) of each sample was also estimated.

The minimum viable population (PMV) for the in situ genetic conservation was estimated by the equation proposed by Silva and Pinto (2009): PMV = Neref * $n /$ Ne. Neref $=$ the effective population size of the reference; $\mathrm{n}=$ the sample size, and $\mathrm{Ne}=$ the effective population size. Effective reference sizes of 150 individuals and 1,000 individuals were used for the long and short-term conservations, respectively (Sebbenn, 2006; Frankham et al., 2014).

\section{Results}

When comparing the populations' allelic richness (AR), the Reflo area was superior. The Nat population presented higher Ar values in the juveniles (3.082) and the Reflo adults (4.343). The Nat and Reflo populations, for those individuals in the juvenile stage, presented exclusive alleles. Only the Reflo population showed complete alleles (three) (Table 1). 
Table 1

Frequencies of the alleles in the microsatellite loci of Schinus terebinthifolia Raddi were located in different populations and at different stages of development. Natural (Nat), Reflorested (Reflo), the total number of individuals sampled $(M)$, and the number of heterozygous individuals $(n)$.

\begin{tabular}{|c|c|c|c|c|c|}
\hline & & \multicolumn{4}{|c|}{ Populations } \\
\hline & & $\begin{array}{l}\text { Nat } \\
\text { Adults }\end{array}$ & $\begin{array}{l}\text { Nat } \\
\text { Juveniles }\end{array}$ & $\begin{array}{l}\text { Reflo } \\
\text { Adults }\end{array}$ & $\begin{array}{l}\text { Reflo } \\
\text { Juveniles }\end{array}$ \\
\hline Locus & $N$ & 74 & 32 & 82 & 121 \\
\hline \multirow[t]{6}{*}{ Saat 09} & (n) & 67 & 23 & 72 & 103 \\
\hline & 1 & - & - & 0.083 & 0.150 \\
\hline & 2 & - & - & 0.410 & 0.345 \\
\hline & 3 & 0.500 & 0.500 & 0.417 & 0.398 \\
\hline & 4 & 0.500 & 0.500 & 0.090 & 0.078 \\
\hline & 5 & - & - & - & 0.029 \\
\hline \multirow[t]{8}{*}{ Saat 17} & (n) & 65 & 31 & 71 & 93 \\
\hline & 1 & - & - & 0.077 & - \\
\hline & 2 & - & - & 0.106 & - \\
\hline & 3 & - & - & 0.127 & 0.086 \\
\hline & 4 & - & - & 0.042 & 0.032 \\
\hline & 5 & 0.600 & 0.258 & 0.380 & 0.462 \\
\hline & 6 & - & - & 0.014 & - \\
\hline & 7 & 0.400 & 0.742 & 0.254 & 0.419 \\
\hline \multirow[t]{6}{*}{ Saat 47} & (n) & 66 & 30 & 74 & 105 \\
\hline & 1 & 0.152 & 0.067 & 0.095 & 0.090 \\
\hline & 2 & 0.470 & 0.367 & 0.865 & 0.857 \\
\hline & 3 & 0.379 & 0.517 & - & 0.033 \\
\hline & 4 & - & 0.033 & 0.041 & 0.019 \\
\hline & 5 & - & 0.017 & - & - \\
\hline \multirow[t]{2}{*}{ Saat 55} & (n) & 69 & 29 & 73 & 119 \\
\hline & 1 & - & - & 0.123 & 0.067 \\
\hline
\end{tabular}




\begin{tabular}{|c|c|c|c|c|c|}
\hline & \multicolumn{3}{|c|}{ Populations } & \multirow[b]{2}{*}{0.678} & \multirow[b]{2}{*}{0.790} \\
\hline & 2 & 0.877 & 0.810 & & \\
\hline & 3 & 0.123 & 0.190 & 0.199 & 0.143 \\
\hline \multirow[t]{8}{*}{ Saat 25} & (n) & 71 & 32 & 80 & 117 \\
\hline & 1 & 0.007 & - & 0.025 & - \\
\hline & 2 & 0.021 & - & 0.081 & 0.051 \\
\hline & 3 & 0.394 & 0.453 & 0.344 & 0.274 \\
\hline & 4 & 0.063 & 0.047 & 0.044 & 0.094 \\
\hline & 5 & 0.049 & 0.094 & 0.481 & 0.547 \\
\hline & 6 & 0.007 & 0.016 & - & - \\
\hline & 7 & 0.458 & 0.391 & 0.025 & 0.034 \\
\hline N. Total Alleles & & 16 & 16 & 23 & 21 \\
\hline $\begin{array}{l}\text { N. Exclusive } \\
\text { Alleles }\end{array}$ & & 0 & 1 & 3 & 1 \\
\hline
\end{tabular}

For the two stages, the Reflo population presented a higher genetic diversity ( $\mathrm{He}=0.553$ and 0.503 for the adults and juveniles, respectively) than the Nat population ( $\mathrm{He}=0.487$ and 0.483 for the adults and juveniles, respectively). The adult and juvenile individuals of the Nat population presented low indexes of fixation $(F)$, which were not significantly different from zero, which allowed one to infer that there was an absence of inbreeding. The values of $(F)$ in the Reflo population were high, 0.310 in the adults and 0.261 in the juveniles (Table 2).

Table 2

Mean indexes of the genetic diversity for the five microsatellite loci of Schinus terebinthifolia Raddi that were located in the different populations and at the different stages of development.

\begin{tabular}{|lllllllll|}
\hline & $\boldsymbol{A}_{\boldsymbol{R}}$ & & Ho & \multicolumn{3}{c}{ He } & \multicolumn{3}{c|}{} \\
\hline & Adults & Juveniles & Adults & Juveniles & Adults & Juveniles & Adults & Juveniles \\
\hline Nat & 2.851 & 3.082 & 0.501 & 0.478 & 0.487 & 0.483 & -0.021 & 0.027 \\
\hline Reflo & 4.343 & 3.953 & 0.385 & 0.374 & 0.553 & 0.503 & $0.310^{*}$ & $0.261^{*}$ \\
\hline Mean & 3.597 & 3.518 & 0.443 & 0.426 & 0.520 & 0.493 & 0.145 & 0.144 \\
\hline
\end{tabular}

$A_{R}$ : allelic richness; $H o$ o observed heterozygosity; $H e$ : expected heterozygosity (genetic diversity of Nei); and $F$ : the coefficient of inbreeding, inferred from the estimation of the fixation index.

* Significant at a $5 \%$ of probability. 
For the adult individuals, the Nat population showed a negative coefficient of consistency ( $\mathrm{Fij}=-0.035)$, which contributed to the absence of genetic structuring of the population. The Reflo population presented a coefficient consistency of 0.338 , indicating that the population means for the studied loci were fullsiblings. For the juvenile stages, the Nat population had a Fij $=0.105$ (half-siblings) and for the Reflo had a Fij $=0.284$ (complete siblings) (Table 3 ).

Table 3

Sample size $(n)$; the effective population size $(\mathrm{Ne})$; the relationship between the effective population size and the sample size $(\mathrm{Ne} / n)$; the minimum viable population with the effective reference size

$P M V\left(\mathrm{Ne}_{\text {ref }}=150\right) ; P M V\left(\mathrm{Ne}_{\text {ref }}=1000\right) ;$ and the coancestry coefficient $\left(F_{i j}\right)$ of the natural populations (Nat) and the reforested populations (Reflo) of Schinus terebinthifolia Raddi.

\begin{tabular}{|c|c|c|c|}
\hline \multirow[b]{2}{*}{ Parameters } & \multirow[b]{2}{*}{ Stages of Development } & \multicolumn{2}{|c|}{ Populations } \\
\hline & & Nat & Reflo \\
\hline \multirow[t]{2}{*}{$n$} & Adults & 74 & 82 \\
\hline & Juveniles & 32 & 121 \\
\hline \multirow[t]{2}{*}{$\mathrm{Ne}$} & Adults & 74.00 & 62.08 \\
\hline & Juveniles & 30.95 & 95.50 \\
\hline \multirow[t]{2}{*}{$\mathrm{Ne} / n$} & Adults & 1.022 & 0.757 \\
\hline & Juveniles & 0.967 & 0.789 \\
\hline \multirow{2}{*}{$\begin{array}{l}P M V \\
\left(N e_{r e f}=150\right)\end{array}$} & Adults & 146.71 & 198.13 \\
\hline & Juveniles & 155.08 & 190.05 \\
\hline \multirow{2}{*}{$\begin{array}{l}P M V \\
\left(N e_{r e f}=1000\right)\end{array}$} & Adults & 978.06 & 1320.87 \\
\hline & Juveniles & 1033.92 & 1267.01 \\
\hline \multirow[t]{2}{*}{$F_{i j}$} & Adults & -0.035 & 0.338 \\
\hline & Juveniles & 0.105 & 0.284 \\
\hline
\end{tabular}

Using the distribution of the individuals by distance class, it was observed that in the Nat (natural) population, the adults presented a degree of kinship of half-brothers in the first and second classes (Fij = 0.186 and 0.150 ). From the distances of $10.77 \mathrm{~m}$, the values of Fij were reduced. The juveniles of this population presented a Fij of 0.112 and 0.115 in the first and third distance classes, respectively. The adults of the Reflo (reforested) population showed Fij values of 0.374 and 0.092 in the first and second distance classes, respectively (up to $170.70 \mathrm{~m}$ ), and the juveniles presented Fij values of 0.303 (full siblings) and 0.034 , respectively (Fig. 1). 


\section{Discussion}

The highest rates of genetic diversity for the reforested (Reflo) population of S. terebinthifolia indicated that the area was established through individuals with high genetic diversity. These values of diversity were higher than those that were observed for the same species in eight natural fragments in the States of Minas Gerais $(\mathrm{He}=0.25)$, Espírito Santo $(\mathrm{He}=0.37)$, and Sergipe (He between 0.24 and 0.49) (ÁlvaresCarvalho et al., 2016). Despite the high genetic diversity index introduced in the Reflo area, reduced diversity among the juveniles was observed. Thus it results in the number of exclusive alleles, which leads to the loss of interest in the alleles, meanly those related to resistance, biotic stresses, and abiotic matter. This reduction of genetic diversity may result from the low gene flow among the fragments of the environment, contributing to the non-random crossing of the individuals; consequently, to the maintenance of endogamy and coancestry in the Reflo population.

When studying natural and reforested areas with the Inga vera species, it was observed that even with the implantation of individuals with high genetic diversity, the juveniles presented an inbreeding coefficient equal to $F=0.303$. The authors argued that habitat fragmentation could alter the reproductive strategies in plant communities and negatively interfere with the plant-pollinator interactions, favoring the dispersal of pollen grains at a closer range. These changes may increase an inbreeding situation, leading to the crossing between related individuals (Cruz Neto et al., 2014).

The adult and juvenile individuals of the Nat population did not present spatial genetic structuring from a distance of $10.77 \mathrm{~m}$, and they were not related from this distance. This finding may be associated with the presence of pollinators and dispersers in the area. It contributes to a better distribution of the alleles and the genotypes, maintaining the genetic diversity $(\mathrm{He})$. The adult individuals of the Reflo population were planted during the reforestation project, so this genetic structure in distance class was not natural.

In the juveniles of the Reflo population, relatives (full-siblings, Fij $=0.284$ ) were observed in the first distance class $(14 \mathrm{~m})$, which was close to that found in the natural area. Although pollinators and dispersers may have occurred in the reforestation area, this supply may not have been enough, as there was still a solid genetic structuring of the juvenile individuals and a loss of gene diversity (Ho, $\mathrm{He}$ and AR). Another factor contributing to the spatial genetic structuring in the dioecious species was individuals displaying one of the genders in a greater quantity in the area, thus providing directed crossings and, consequently, related offspring.

The effective population size $(\mathrm{Ne})$ inferred the effects of genetic drift in each population at different stages of their life. The adults in the Nat population were not suffering from genetic drift. Thus, the 74 individuals of the population corresponded to an ideal population (panmictic), with random crosses, without selection, migration, mutation, kinship, and endogamy (Sebbenn and Seoane, 2005). In the juveniles, endogamy and coancestry, even in low values, altered the Ne. In the Reflo population, the effect of genetic drift was lower than in the juveniles, inferring that if all had reached a fertile age, the genetic representativity of the individuals would have been $78.9 \%$. The values found in the present study were higher than those found in studies in the natural areas of the Atlantic Forest, the Caatinga, and the 
Ecotone regions of the State of Sergipe. In these regions, estimations of 23, 15, and 42 of $\mathrm{Ne}$, respectively, were obtained. These findings have allowed one to infer that they represented $50 \%$ of an ideal panmictic population (Álvares-Carvalho et al., 2015), which implies the necessity of conserving these populations.

The relationship between the effective size $(\mathrm{Ne})$ and the sample size $(\mathrm{n})$ is of fundamental importance in planning conservation strategies. A balance considering demographic events, such as the temporal fluctuations in population size, the presence of structure and the inbreeding, the differences in infertility, as well as the asynchronous flowering, the Ne were very close to the number of individuals that were collected (Loveless and Hamrick, 1984). For the Reflo population, the relationship was higher in juveniles due to their lower values of coancestry and inbreeding when compared to the adults.

Based on the values recommended for conserving populations in short ( $\mathrm{Ne} \geq 150)$ and long periods ( $\mathrm{Ne}$ $\geq 1000$ ), both populations need conservation actions to maintain their genetic diversity and contain the effects of genetic drift. In a study with Centrolobium tomentosum, a native species from Atlantic Forest is pollinated by bees. The adverse effects of inbreeding on the population's effective size in adults' and juveniles' natural remnants and the restoration areas were observed. The authors attributed these facts to the small population's size, which was associated with the spatial genetic structures and the pollination service deficits (Sujii et al., 2017).

It is essential to increase the gene flow among the fragments located around the reforested area, allowing for the maintenance of the genetic diversity of the individuals implanted throughout the generations and, consequently, the generation's self-sustainability of the generations settlement. An alternative would be installing new reforestation projects, even on a smaller scale, when based upon the connectivity of the fragments.

These new areas may then be the sources of alleles since they will allow for the displacement of the pollinators and the dispersers between the fragments and the reforested population. Through these actions, the reforested area will serve as a supplier of seeds for future reforestation projects in the Atlantic Forest area.

\section{Declarations}

\section{Acknowledgments}

We thank the National Council for Scientific and Technological Development - Brazil (CNPq), the Coordination for the Improvement of Higher Education Personnel - Brazil (CAPES ), Federal University of Sergipe, and the Research Group on Conservation, Breeding and Management of Genetic Resources (GENAPLANT).

\section{Ethics declarations}

\section{Conflict of interest}


All the authors of this manuscript declare that they have no conflict of interest.

\section{Ethical approval}

This article does not contain any studies with human participants or animals performed by any of the authors.

\section{Data availability}

The datasets generated during and/or analyzed during the current study are available from the corresponding author on reasonable request.

\section{Author Contributions}

EMSS conducted the research and wrote the text, RSM and RAF guided the research, revised the text and contributed to the writing of the manuscript, SVAC contributed to obtaining the research data, in the writing and revision of the text. All authors contributed to the article and approved the submitted version.

\section{References}

1. Álvares-Carvalho SV et al (2015) Schinus terebinthifolia: Population structure and implications for its conservation. Biochem Syst Ecol 58:120-125

2. Álvares-Carvalho SV et al (2016) Structure and genetic diversity of natural Brazilian pepper populations (Schinus terebinthifolia Raddi). Genet Mol Res 15:1-13

3. Álvares-Carvalho SV et al (2017) Restoration over time and sustainability of Schinus terebinthifolia Raddi. Genet Mol Res 16:1-9

4. Cruz Neto $O$ et al (2014) Genetic and ecological outcomes of Inga vera Subsp. affinis (Leguminosae) tree plantations in a fragmented tropical landscape. PLoS One 9:1-8

5. Frankham R, Bradshaw CJA, Brook BW (2014) Genetics in conservation management: Revised recommendations for the 50/500 rules, Red List criteria and population viability analyses. Biol Conserv 170:56-63

6. Goudet J (1995) FSTAT. (Version 2.9.3.2.): a computer program to calculate F-statistics. J Hered 86:485-486

7. Hardy O, Vekemans X (2002) SPAGeDi: a versatile computer program to analyse spatial genetic structure at the individual or population levels. Mol Ecol Notes 2:618-620

8. Jesus BC, Gomes LJ (2013) Importância socioeconômica, in: Gomes, L.J., Silva-Mann, R., Mattos, P.P., Rabbani, A.R.C. (Eds.), Pensando a biodiversidade: aroeira (Schinus terebinthifolia Raddi). Editora da UFS, São Cristóvão, pp. 36-53

9. Kageyama P, Gandara FB (2004) Recuperação de áreas ciliares. In: Rodrigues RR, Leitão Filho HF (eds) Matas ciliares: Conservação e recuperação. FAPESP, São Paulo, pp 249-269 
10. Lenzi M, Orth Al (2004) Fenologia reprodutiva, morfologia e biologia floral de Schinus terebinthifolia Raddi (Anacardeaceae), em restinga da llha de Santa Catarina. Brasil Biotemas 17:67-89

11. Loiselle BA et al (1995) Spatial genetic structure of a tropical understory shrub, Psychotria officinalis (Rubiaceae). Am J Bot 82:1420-1425

12. Loveless MD, Hamrick JL (1984) Ecological determinants of genetic structure in plant populations. Annu Rev Ecol Evol Syst 15:65-95

13. Mijangos JL, et l., 2015. Contribution of genetics to ecological restoration. Mol. Ecol. 24, 22-37

14. Nei M (1978) Estimation of average heterozygosity and genetic distance from a small number of individuals. Genetics 89:583-590

15. Peakall R, Smouse PE (2012) GenAlEx 6.5: genetic analysis in Excel. Population genetic software for teaching and research - an update. Bioinformatics 28:2537-2539

16. Rodrigues R, Brancalion P, Isernhagen I (2009) Pacto pela restauração da Mata Atlântica: referencial dos conceitos e ações de restauração florestal. LERF/ESALQ, São Paulo

17. Rodrigues RR et al (2011) Large-scale ecological restoration of high-diversity tropical forests in SE Brazil. For Ecol Manag 261:1605-1613

18. Sebbenn AM (2002) Number of mother tree and genetics concepts in the collection of seeds for reforestation native species. Rev Inst Flor 14:115-132

19. Sebbenn AM (2006) Sistemas de reprodução em espécies tropicais e suas implicações para a seleção de árvores matrizes para reflorestamentos ambientais. In: Higa AR, Silva LD (Coord.) Pomar de sementes de espécies florestais nativas. FUPEF, Curitiba, pp 93-138

20. Sebbenn AM, Kageyama PY, Vencovsky R (2003) In situ genetic conservation and number of tree for seed collect in Genipa americana L. population. Sci. For. 63, 13-22, 2003

21. Sebbenn AM, Seoane CES (2005) Estimative of inbreeding effective size by genetic markers. Rev Árv 29:1-17

22. SERGIPE (2014) Secretaria de Estado do Meio Ambiente e dos Recursos Hídricos. Diagnóstico florestal de Sergipe. Aracaju

23. Silva TA, Pinto LVA (2009) Identification of mother trees of six allogamy species in a forest fragment aiming to the production of seedlings with genetic variability. Rev Agrogeoambiental 1:56-62

24. SOS Mata Atlântica. Relatório anual 2016. São Paulo (2016) https://www.sosma.org.br/wpcontent/uploads/2013/05/AF_RA_SOSMA_2016_web.pdf (accessed 14 dezember 2017)

25. Sujii PS et al (2017) Recovery of genetic diversity levels of a Neotropical tree in Atlantic Forest restoration plantations. Biol Conserv 211:110-116

26. Vencovsky R, Crossa J (2003) Measurements of Representativeness Used in Genetic Resources Conservation and Plant Breeding. Crop Sci 43:1912-1921

27. Weir BS, Cockerham CC (1984) Estimating F-statistics for the analysis of population structure. Evolution 38:1358-1370 
28. Williams DA, Sternberg LDSL, Hughes CR (2002) Characterization of polymorphic microsatellite loci in the invasive Brazilian pepper, Schinus terebinthifolia. Mol Ecol Notes 2:231-232

\section{Figures}
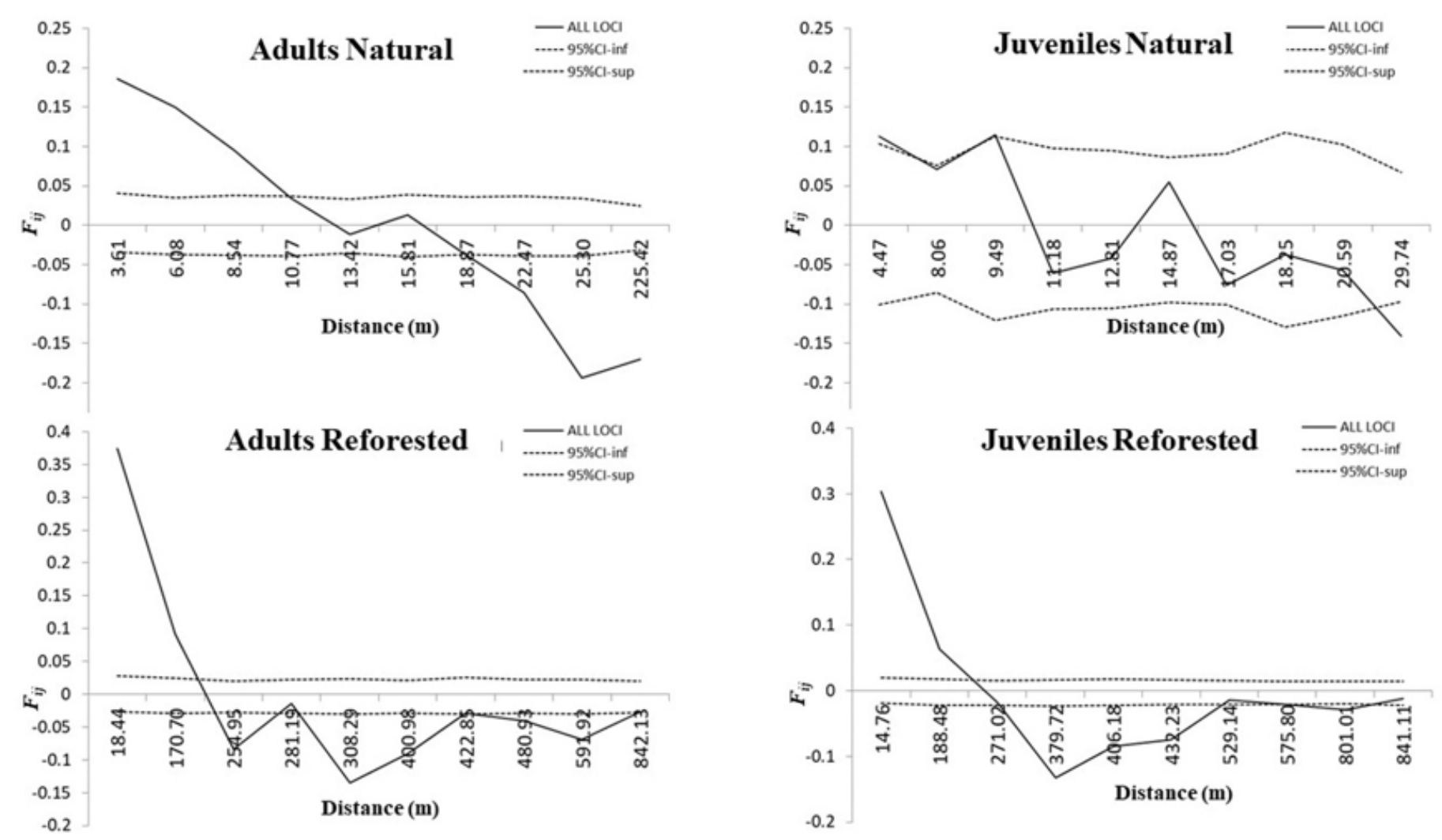

\section{Figure 1}

Correlograms of the coancestry coefficients $\left(F_{i j}\right)$ of Schinus terebinthifolia Raddi, by distance classes, in the Nat (natural) and the Reflo (Reflorested) populations, at the different stages of development. The dashed lines represent the confidence intervals, at a $95 \%$ of probability.

The Nat population presented individuals with a greater genetic representativeness (adults $=1,000$ and juveniles $=0.967$ ), when compared to the Reflo population (adults $=0.757$ and juveniles $=0.789$ ). 